\title{
Total Synthesis of Seven Indole Alkaloids
}

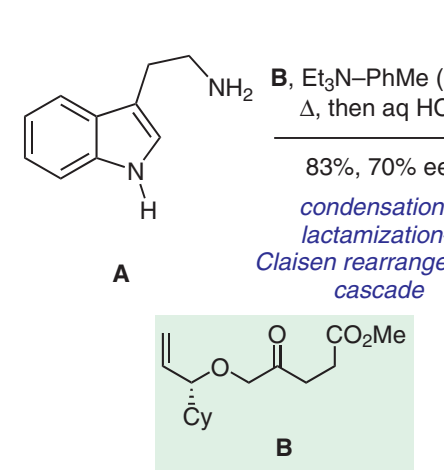

1. $\mathrm{Ph}_{3} \mathrm{PBr}_{2}, \mathrm{NBu}_{4} \mathrm{Br}$, imidazole $\mathrm{CH}_{2} \mathrm{Cl}_{2}$

2. $\left.\left[\mathrm{CH}_{2}\left(\mathrm{Ph}_{2} \mathrm{P}\right)_{2} \mathrm{AuCl}\right)_{2}\right](2 \mathrm{~mol} \%)$ $\mathrm{Na}_{2} \mathrm{CO}_{3}, h v(365 \mathrm{~nm}), \mathrm{MeCN}$

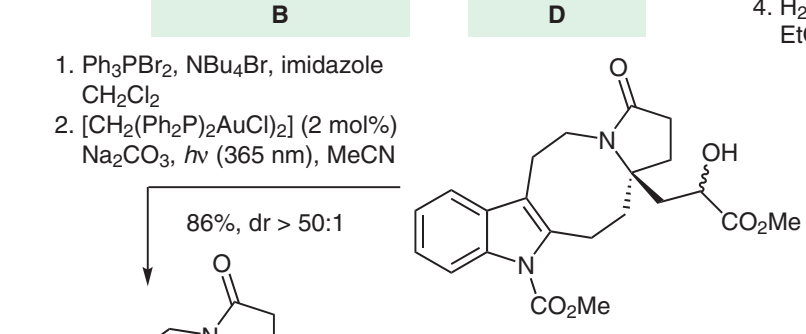

H<smiles>COP(=O)(OC)C(=[NH2+])C(C)=O</smiles>

D

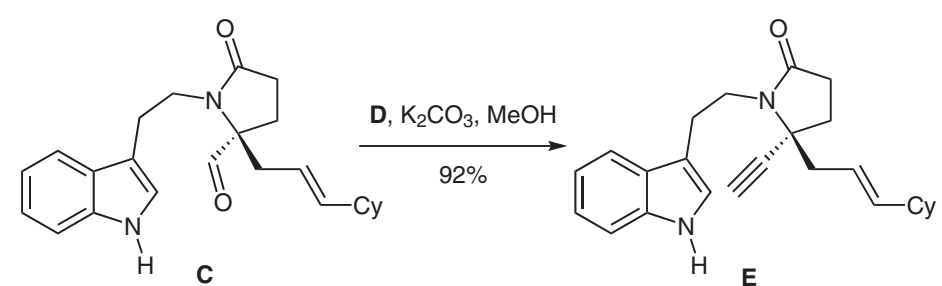

c

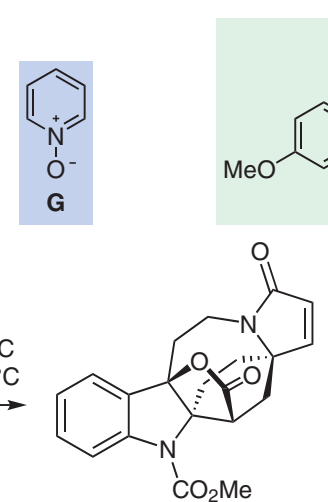

(+)-Grandilodine C

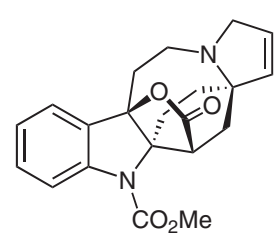

(+)-Lapidilectine B
$\mathrm{Me}_{3} \mathrm{OBF}_{4}, \mathrm{CH}_{2} \mathrm{Cl}_{2}$ $4 \AA \mathrm{MS}$, then $\mathrm{NaBH}_{4}$ $\mathrm{MeOH}, 0^{\circ} \mathrm{C}$ $47 \%$

Key words

Passerini reaction

photoredox catalysis

gold catalysis

indole alkaloids

pyrroloazocine motif

Significance: A set of seven indole alkaloids were synthesized by the Echavarren group through common precursor $\mathbf{I}$. The alkaloids all contain a pyrroloazocine core and were shown to reverse multidrug resistance in cancer cells. Further experiments provided insights into a biosynthetic mechanism.
Comment: The use of an imine formationlactamization-rearrangement cascade provides rapid access to $\mathbf{C}$. A set of homologations and gold cyclizations led to the desired carbon framework in I. Functional group manipulations then led to a collection of related natural products.

SYNFACTS Contributors: Erick M. Carreira, Philipp Sondermann Synfacts 2018, 14(05), 0445 Published online: 17.04.2018 DoI: 10.1055/s-0037-1609840; Reg-No.: C01818SF 